\title{
Prognostic significance of p53 immunohistochemical expression in adenoid cystic carcinoma of the salivary glands: a meta- analysis
}

\author{
Qinglin $\mathrm{Li}^{1,3, *}$, Ping Huang ${ }^{1,3, *}$, Chuanming Zheng ${ }^{2,3}$, Jiafeng Wang ${ }^{2,3}$ and Minghua \\ $\mathbf{G e}^{2,3}$ \\ ${ }^{1}$ Department of Pharmacy, Zhejiang Cancer Hospital, East Banshan Road, Hangzhou, Zhejiang Province, China \\ 2 Department of Head and Neck Surgery, Zhejiang Cancer Hospital, Hangzhou, Zhejiang Province, China \\ ${ }^{3}$ Zhejiang Key Laboratory of Head and Neck Tumor, Zhejiang Cancer Hospital, Hangzhou, Zhejiang Province, China \\ * These authors have contributed equally to this work
}

Correspondence to: Minghua Ge, email: gemingh@163.com

Keywords: adenoid cystic carcinoma, salivary glands, p53 expression, prognosis, meta-analysis

Received: August 15, $2016 \quad$ Accepted: January 06, $2017 \quad$ Published: February 11, 2017

Copyright: Li et al. This is an open-access article distributed under the terms of the Creative Commons Attribution License (CC-BY), which permits unrestricted use, distribution, and reproduction in any medium, provided the original author and source are credited.

\section{ABSTRACT}

Adenoid cystic carcinoma of salivary glands is a rare adenocarcinoma and has been placed in "high-risk" category as poor long-term prognosis. The purpose of this study was to investigate $\mathrm{p} 53$ protein expression in adenoid cystic carcinoma of salivary glands and its correlation with clinicopathological parameters and prognosis. Literatures were searched from PubMed, Embase, Cochrane Library and Web of Science, which investigated the relationships between p53 expression and pathological type, clinical stage, local recurrence, metastasis, nerve infiltration and overall survival. A total of 1,608 patients from 36 studies were included in the analysis. The results showed that p53-postive expression rate was $49 \%$ in adenoid cystic carcinoma of salivary glands (OR=10.34, 95\%CI: 4.93-21.71, $P<0.0001)$. The p53-postive expression was closely related to tumor types (OR=0.30, 95\%CI: 0.14$0.65, P<0.0001)$. The tumor with solid histological subtype had a strong positive correlation with p53 expression. The combined analysis revealed that the p53-positive expression rate among patients in T1and T2 stage was $41.4 \%$, compared to $53.2 \%$ among those in T3 and T4 stage. However, there was no significant correlation between tumor stage and p53 expression ( $O R=0.47,95 \% \mathrm{CI}: 0.17-1.29, P=0.14)$. Besides, compared to patients with p53-negative expression, those with p53-positive expression had a greater chance of developing metastasis, local recurrence and nerve infiltration as well as poorer 5 -year overall survival $(P<0.01)$.In conclusion, the p53 expression is related to the survival of adenoid cystic carcinoma of salivary glands. It can be considered as the auxiliary detection index in treatment and prognosis of adenoid cystic carcinoma of salivary glands.

\section{INTRODUCTION}

There is significant difference in the incidence of salivary gland tumors in different countries, which is 0.15-1.6/100 thousand in China according to the WHO report. Malignant salivary gland tumors constitute less than $1 \%$ of all the malignancies while $21-46 \%$ of all salivary gland tumors $[1,2]$. Adenoid cystic carcinoma (ACC) is a rare variant of adenocarcinoma that most often arises in the salivary glands [3], and comprises approximately $1 \%$ of all malignant tumors of oral and maxillofacial origin [4]. Adenoid cystic carcinoma (ACC) constitutes approximately $4 \%$ of salivary epithelial tumors, which is the most common malignant tumor of minor salivary glands and the second most common malignant tumor involving major salivary glands. Almost $70 \%$ of minor salivary gland tumors are malignant, and ACC is the most common type [5,6]. It can occur at any age, but 40-60 years of age are most commonly affected, and there are slightly more women than men. 
Table 1: Main characteristics of all the studies included in the meta-analysis

\begin{tabular}{|c|c|c|c|c|c|c|c|c|c|c|c|c|}
\hline \multirow{2}{*}{$\begin{array}{l}\text { First } \\
\text { Author, } \\
\text { Year }\end{array}$} & \multirow{2}{*}{$\begin{array}{l}\text { Origin } \\
\text { County }\end{array}$} & \multirow{2}{*}{$\begin{array}{l}\text { Control } \\
\text { Source }\end{array}$} & \multirow{2}{*}{$\begin{array}{l}\text { Detection } \\
\text { Method }\end{array}$} & \multirow{2}{*}{$\begin{array}{l}\text { Tumor } \\
\text { Stage }\end{array}$} & \multirow{2}{*}{$\begin{array}{l}\text { No.of } \\
\text { patients }\end{array}$} & \multicolumn{3}{|c|}{ Number of samples } & \multicolumn{3}{|c|}{ Histopathological pattern } & \\
\hline & & & & & & SACC & Control & Cribriform & Tubular & \begin{tabular}{|l|} 
Cribriform \\
and \\
Tubular \\
\end{tabular} & Solid & \\
\hline $\begin{array}{l}\text { Guo S, } \\
2002\end{array}$ & China & NSG & SP & I-IV & 57 & 45 & 12 & 23 & 17 & 40 & 5 & 8 \\
\hline $\begin{array}{l}\text { Peng X, } \\
1998\end{array}$ & China & NSG & SP & $\mathrm{I}-\mathrm{IV}$ & 60 & 50 & 10 & 24 & 22 & 46 & 4 & 8 \\
\hline $\begin{array}{l}\text { Danyel, } \\
2006\end{array}$ & Brazil & NS & SP & I-IV & 107 & 107 & NS & 58 & 27 & 80 & 22 & 6 \\
\hline $\begin{array}{l}\text { Kazuaki C, } \\
2007\end{array}$ & Japan & NS & SP & I-IV & 27 & 27 & NS & 12 & 8 & 20 & 7 & 6 \\
\hline $\begin{array}{l}\text { Gabriele, } \\
2005\end{array}$ & Italy & NSG & SP & I-IV & 42 & 21 & 21 & 11 & 2 & 13 & 8 & 8 \\
\hline \begin{tabular}{|l} 
Liu F, \\
2004 \\
\end{tabular} & China & BSG & SP & NS & 52 & 47 & 5 & 17 & 12 & 29 & 18 & 8 \\
\hline $\begin{array}{l}\text { Lin J, } \\
2004\end{array}$ & Japan & NS & SP & NS & 39 & 39 & NS & 17 & 13 & 30 & 9 & 8 \\
\hline \begin{tabular}{|l} 
Jose E, \\
2008 \\
\end{tabular} & USA & NS & SP & NS & 47 & 47 & NS & 36 & 4 & 40 & 7 & 6 \\
\hline $\begin{array}{l}\mathrm{He} \text { W, } \\
2012\end{array}$ & China & BSG & SP & I-IV & 46 & 34 & 12 & NS & NS & 14 & 20 & 7 \\
\hline $\begin{array}{l}\text { Vesa J.k, } \\
1997\end{array}$ & Finland & BSG & SP & I-IV & 219 & 103 & 116 & NS & NS & NS & NS & 7 \\
\hline \begin{tabular}{|l} 
Helen P, \\
1996 \\
\end{tabular} & USA & NS & NS & NS & 13 & 13 & NS & NS & NS & NS & NS & 5 \\
\hline $\begin{array}{l}\text { Wajiha A, } \\
2011\end{array}$ & Pakista & NS & SP & I-III & 40 & 40 & NS & 18 & 1 & 19 & 5 & 6 \\
\hline $\begin{array}{l}\text { Zhang DS, } \\
2005\end{array}$ & China & NSG & SP & I-IV & 40 & 38 & 2 & NS & NS & 32 & 6 & 7 \\
\hline $\begin{array}{l}\text { Rieko D, } \\
1999\end{array}$ & Japan & NS & SP & NS & 31 & 31 & NS & 11 & 17 & 28 & 3 & 6 \\
\hline $\begin{array}{l}\text { T.Kiyoshima, } \\
2001\end{array}$ & Japan & NS & SP & NS & 17 & 17 & NS & 3 & 8 & 11 & 6 & 6 \\
\hline $\begin{array}{l}\text { O Ben-lzhak, } \\
2007\end{array}$ & Israel & Paracancer & SP & NS & 66 & 66 & 66 & NS & NS & NS & NS & 6 \\
\hline $\begin{array}{l}\text { Wang XF, } \\
2014\end{array}$ & China & Paracancer & SP & I-IV & 36 & 36 & 10 & 15 & 9 & 24 & 1 & 8 \\
\hline $\begin{array}{l}\text { Wei WT, } \\
2007\end{array}$ & China & NS & SP & I-IV & 39 & 39 & NS & NS & NS & NS & NS & 5 \\
\hline $\begin{array}{l}\text { Natheer H, } \\
2009\end{array}$ & Iraq & BSG & SP & I-IV & 12 & 12 & 10 & 3 & 6 & 9 & 3 & 8 \\
\hline $\begin{array}{l}\text { YUZOY, } \\
1996\end{array}$ & Japan & NS & NS & I-IV & 21 & 21 & NS & 7 & 2 & 9 & 12 & 6 \\
\hline $\begin{array}{l}\text { Zhu YM, } \\
2003\end{array}$ & China & NS & SP & NS & 36 & 36 & NS & 19 & 13 & 32 & 4 & 6 \\
\hline $\begin{array}{l}\text { Marina, } \\
2009\end{array}$ & Brazil & NSG & SP & II-IV & 26 & 22 & 4 & 13 & 2 & 15 & 7 & 8 \\
\hline $\begin{array}{l}\text { Wang YS, } \\
2011\end{array}$ & China & BSG & SP & NS & 45 & 35 & 10 & NS & NS & NS & NS & 6 \\
\hline $\begin{array}{l}\text { Hu HQ, } \\
2013\end{array}$ & China & NSG. & SP & NS & 32 & 16 & 16 & NS & NS & NS & NS & 6 \\
\hline $\begin{array}{l}\text { F. A. A, } \\
2004\end{array}$ & Brazil & BSG & SP & NS & 30 & 15 & 15 & NS & NS & NS & NS & 6 \\
\hline $\begin{array}{l}\text { Kyoichi } \\
\mathrm{K}, 2013\end{array}$ & Japan & NS & SP & I-IV & 32 & 32 & NS & NS & NS & 23 & 7 & 5 \\
\hline \begin{tabular}{|l} 
Q. R. Z, \\
1997 \\
\end{tabular} & China & NS & SP & I-IV & 27 & 27 & NS & NS & NS & NS & NS & 5 \\
\hline \begin{tabular}{|l} 
Stalen N, \\
1997 \\
\end{tabular} & Norway & Paracancer & SP & I-IV & 41 & 41 & 41 & NS & NS & NS & NS & 7 \\
\hline $\begin{array}{l}\text { ANDERS N, } \\
2000\end{array}$ & Sweden & BSG & SP & NS & 123 & 55 & 68 & NS & NS & NS & NS & 6 \\
\hline $\begin{array}{l}\text { Liu H, } \\
2013\end{array}$ & China & NSG & SP & NS & 50 & 40 & 10 & NS & NS & NS & NS & 6 \\
\hline
\end{tabular}




\begin{tabular}{|c|c|c|c|c|c|c|c|c|c|c|c|c|}
\hline $\begin{array}{l}\text { MWengh- } \\
\text { oefer,2008 }\end{array}$ & Germany & NSG & SP & NS & 10 & 3 & 7 & NS & NS & NS & NS & 7 \\
\hline $\begin{array}{l}\text { Min J, } \\
2013\end{array}$ & Korea & BSG & SP & NS & 20 & 10 & 10 & NS & NS & NS & NS & 6 \\
\hline $\begin{array}{l}\text { L.C.J, } \\
2014\end{array}$ & China & NS & SP & I-IV & 35 & 35 & NS & NS & NS & NS & NS & 5 \\
\hline $\begin{array}{l}\text { Chen J G, } \\
1999\end{array}$ & China & NSG & SP & IV & 40 & 20 & 20 & NS & NS & 8 & 12 & 6 \\
\hline $\begin{array}{l}\text { Carolina C, } \\
2012\end{array}$ & Brazil & BSG & SP & NS & 18 & 4 & 14 & NS & NS & NS & NS & 6 \\
\hline $\begin{array}{l}\text { MaoMing, } \\
2002\end{array}$ & China & NSG & SP & NS & 32 & 22 & 12 & NS & NS & NS & NS & 5 \\
\hline
\end{tabular}

Abbreviations: SACC: salivary glands adenoid cystic carcinoma, NSG: normal salivary glands, BSG: benign tumors of salivary glands, NS: not stated, SP: streptavidin-perosidase in imuunohistcochemical staining.

The three major growth patterns of salivary glands adenoid cystic carcinoma (SACC) are tubular, cribriform, and solid. One of the important prognostic factors is the histological grade, which is determined by the solid tumor component percentage [7].The clinical and pathological characteristics include slow growth, perineural invasion, distant metastasis, and potential local recurrence[8, 9]. The natural history of SACC is best described that 10year overall survival (OS) for patients is about $50 \%$, but locoregional and distant recurrence after a short diseasefree interval are common $[9,10]$. Once metastatic disease is present, case series of salivary ACC suggest that the median duration of survival is about 3 years. Although complete surgical resection and additional radiotherapy have been shown to improve long-term survival, the prognosis of adenoid cystic carcinoma remains poor $[11,12]$. Accordingly, it is very important to objectively predict prognosis of patients with tumor resection and the development of metastasis. To improve patient outcomes, it is important to identify clinical markers that may predict prognosis and response to specific therapies. However, there are no established biomarkers that correlate with the outcome and therapeutic response in patients with SACC [13].

Because of the rarity of SACC, there are few clinical trials investigating the prognostic indicator. The aim of this systematic review was to assess the association between p53 immunohistochemical expression and pathological types, clinical stage, local recurrence, metastasis, nerve infiltration and survival, to observe the expression of p53 in SACC and its correlation with clinicopathological parameters and prognosis, which may be useful for planning the management and assessing the prognosis.

\section{RESULTS}

\section{Study selection procedures}

The study selection procedure is presented in Figure1. In the initial literature search, 376 studies matched the search terms, of which 41 studies were excluded due to overlapping data sets. And 227 studies were ruled out because apparent irrelevance was found when reading the title and/or abstract. Additional 8 relevant studies from the reference list were included. By reading through the full text of the remaining studies, 74 studies were excluded ( p53 was not detected by IHC in 6 studies, 56 studies had no relevant outcomes, 6 studies were cell experiments or a single case report, and 6 studies were letters, summary, comments or correspondences). Moreover, 6 studies were ruled out due to duplicate patients. Finally, there were 36 articles left with sufficient data for extraction.

\section{Study characteristics}

Thirty-six studies [2, 6-7, 12, 14-45] published between 1996 and 2015 were eligible for this metaanalysis. The total number of patients included was 1,608, ranging from 10 to 219 patients per study. The major characteristics of the 36 eligible publications are reported in Table 1. The studies were conducted in 13 countries and 5 continents (Asia: China, Japan, Korea, Pakista, Israel, Iraq; Europe: Finland, Noraway, Sweden, Italy, Germany; North America: USA; South America: Brazil). p53 expression was detected in all patients in the eligible studies using IHC. The control group was set up in 23 studies, including tissues of normal salivary glands, benign tumour of salivary glands or paracancer tissues. Tumor stage was evaluated in 20 studies, and histopathological types of SACC were provided in 23 studies.

\section{Meta-analysis}

\section{Meta-analysis of p53 expression between the SACC group and the control group}

p53 positive expression in the adenoid cystic carcinoma of the salivary glands group and the control group (normal salivary glands, benign tumor of salivary glands or paracancer tissues) were compared in nineteen eligible studies, with 672 cases of SACC tissues and 329 cases of control tissues. It was found that p53 was positive in 448 cases and 67 cases, respectively. The heterogeneity 
of the 19 studies was tested, and the statistically significant heterogeneity was observed between the studies $\left(\mathrm{I}^{2}=57 \%\right.$, $P=0.001)$. The results showed that $\mathrm{p} 53$ was expressed at a high level in SACC tissues $(\mathrm{OR}=10.34,95 \% \mathrm{CI}$ : 4.9321.71, $P<0.00001)$ (Figure 2).

Sensitivity analysis did not show any significant difference when meta-analysis was repeated after each individual study was omitted or after the studies were excluded. Begg's funnel plot was performed to assess the publication bias in the literature. All 19 eligible studies investigating p53 expression between the SACC group and the control group yielded a Begg's tests core of $\mathrm{P}=0.401$, according to the funnel plot (Figure 3 ), and there was no publication bias in these analyses.

Meta-analysis of p53 expression in the different histopathological types of SACC

17 of 36 studies investigated the association between p53 expression and histopathological types of patients with adenoid cystic carcinoma of the salivary

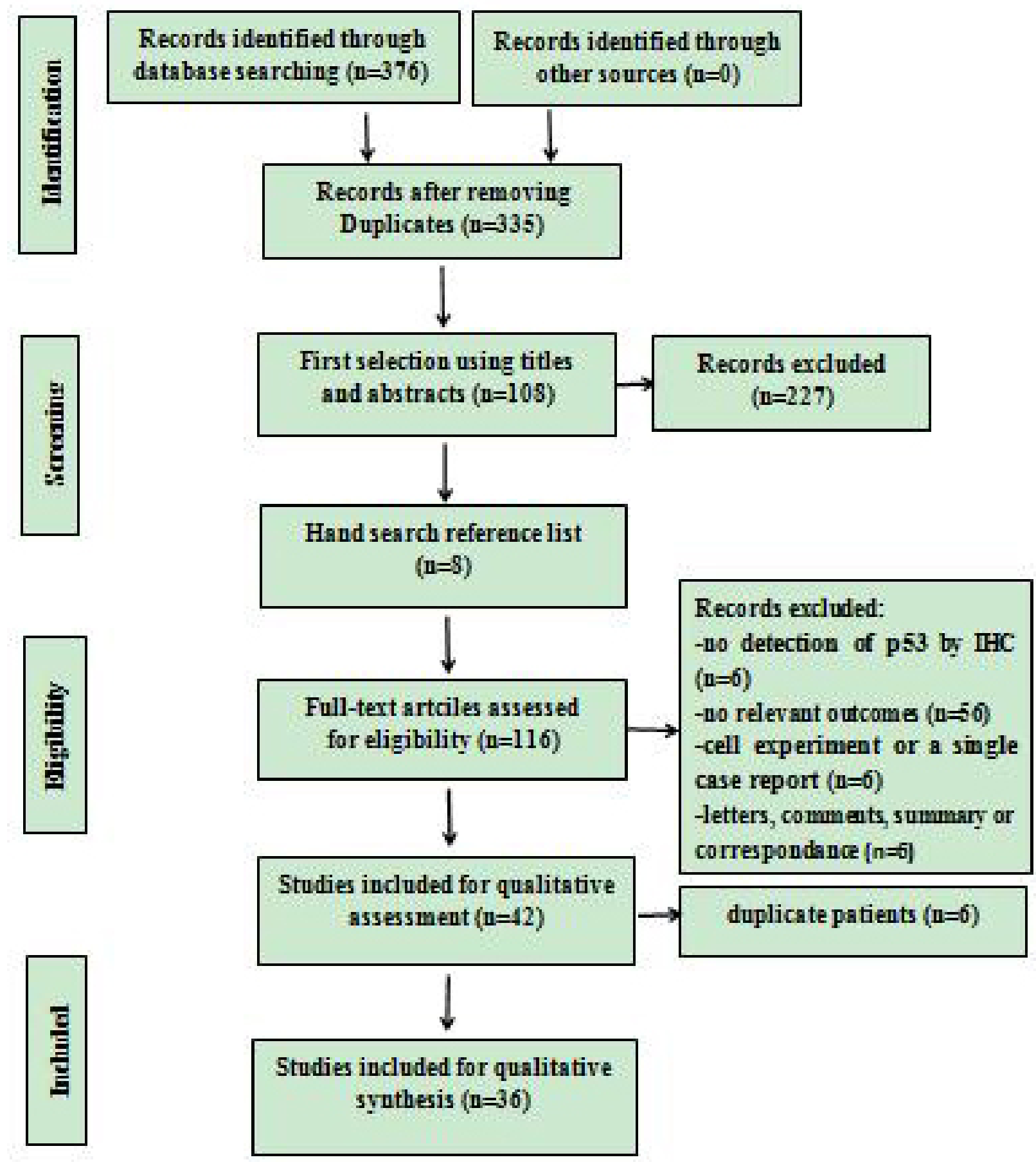

Figure 1: Flowchart of the study selection. 
SACC Control Odds Ratio Odds Ratio

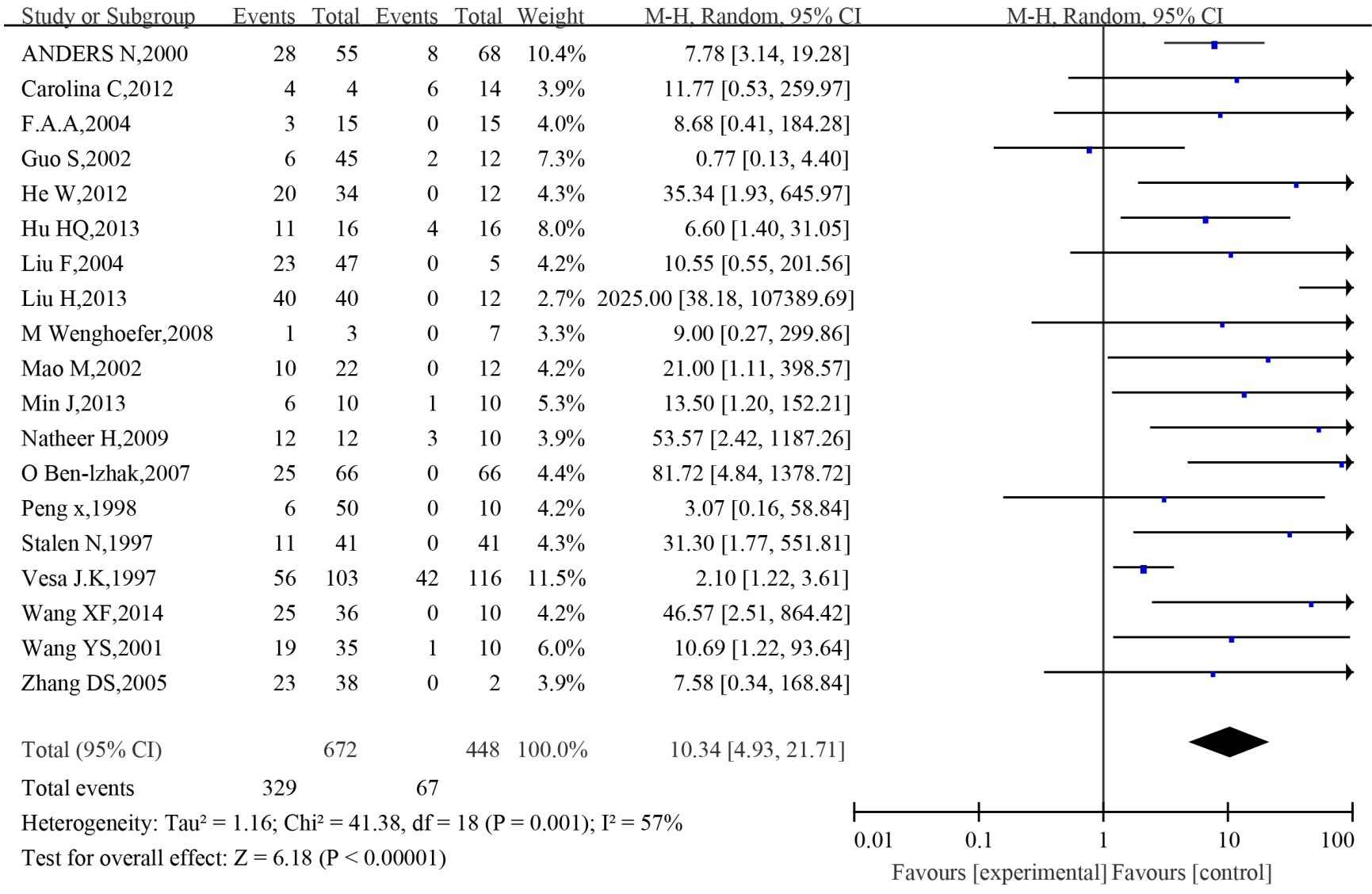

Figure 2: The forest plot of the meta-analysis of p53 expression between the adenoid cystic carcinoma of the salivary glands group and the control group.

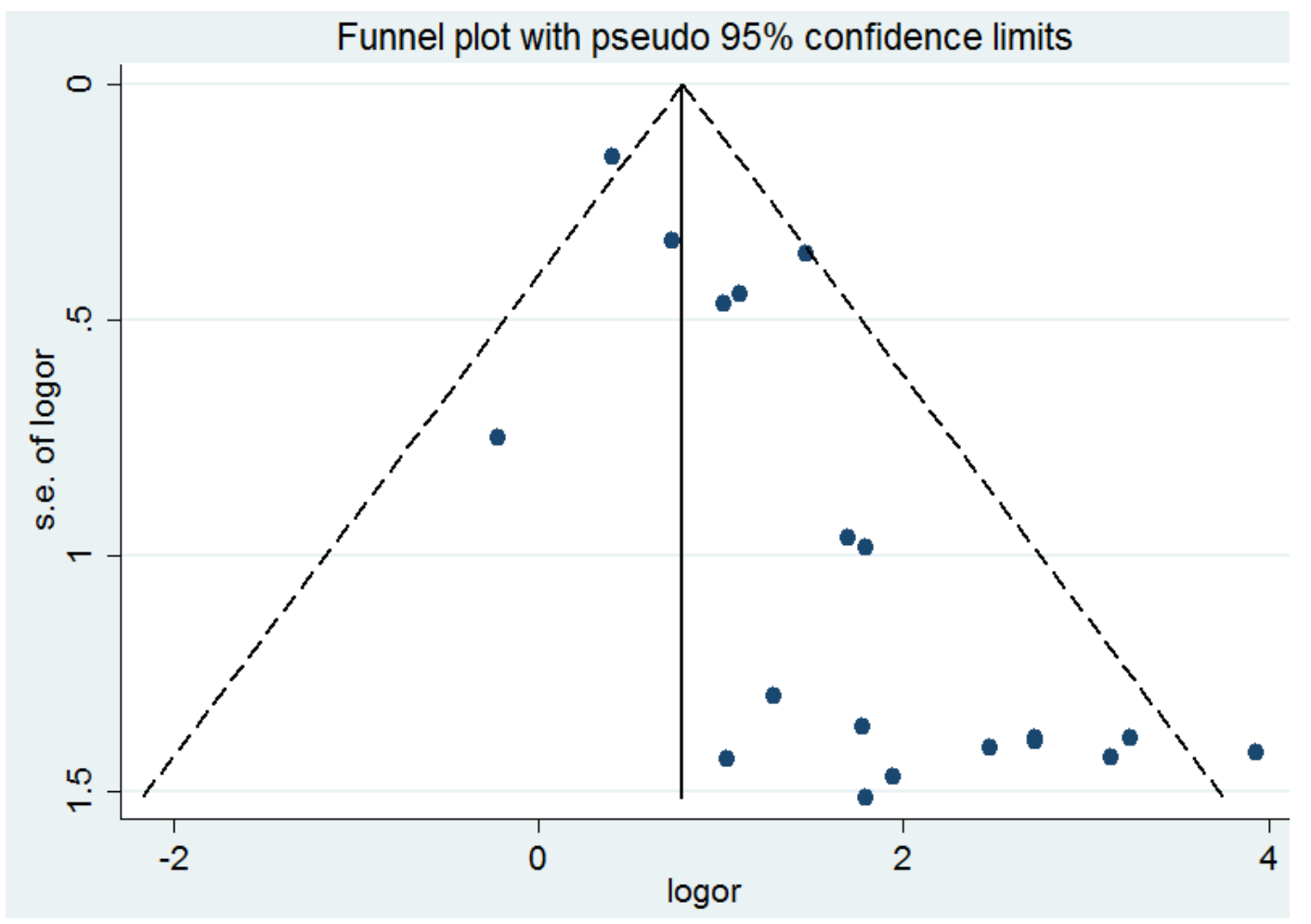

Figure 3: Begg's funnel plot of the potential publication bias of included studies. 


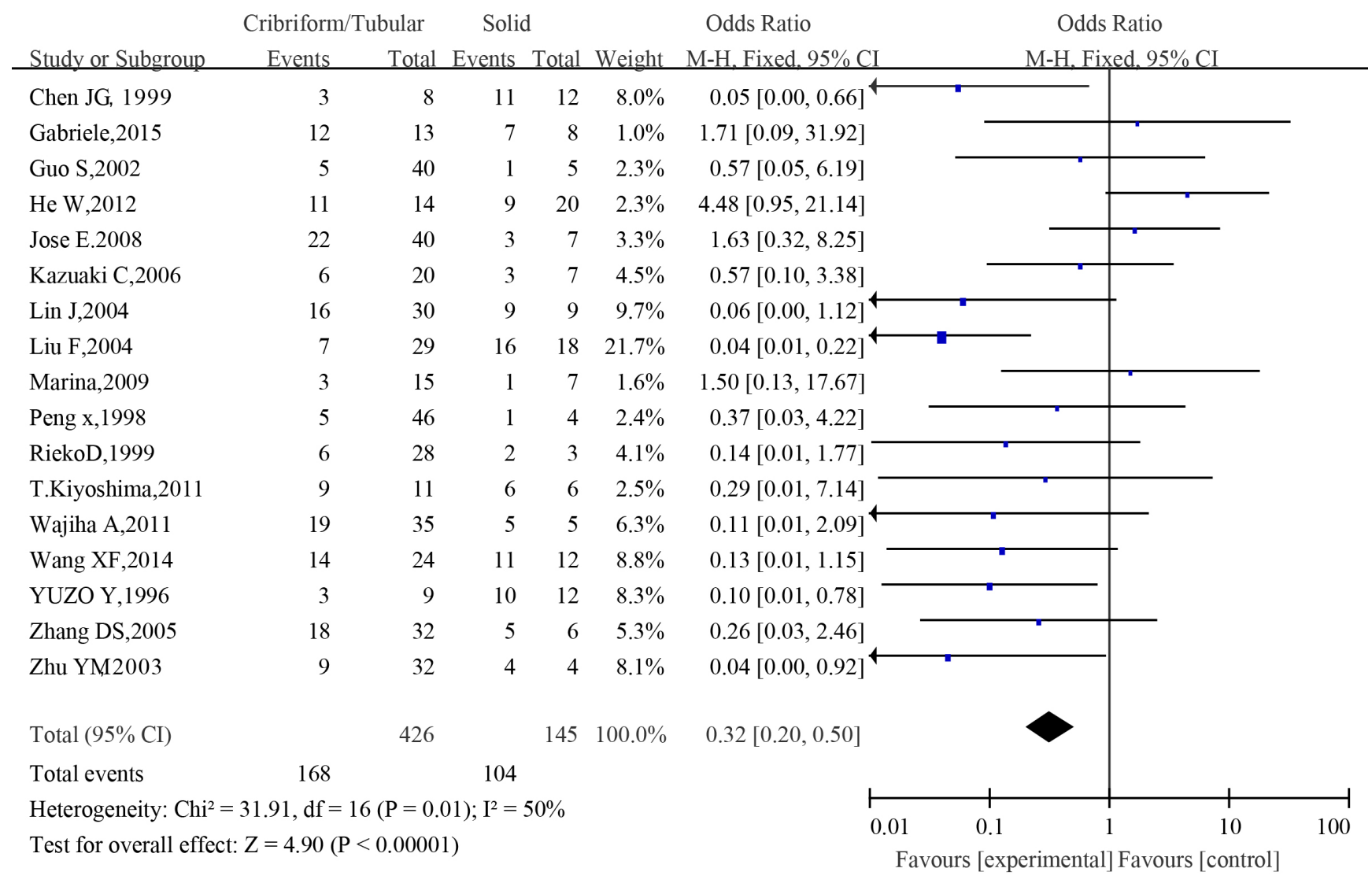

Figure 4: The forest plot of the meta-analysis between p53 expression in the cribriform/ tubular and solid types of salivary glands adenoid cystic carcinoma.

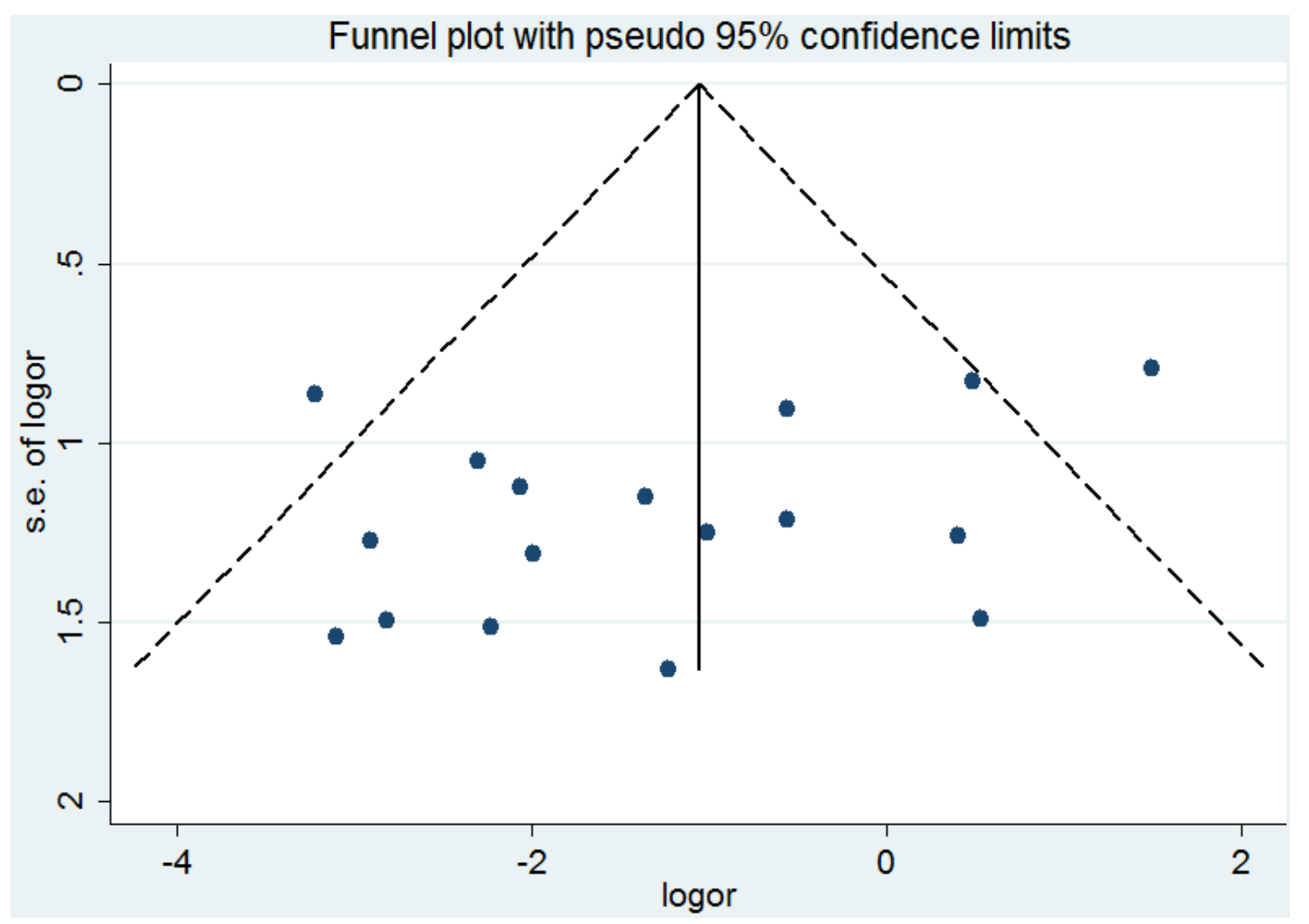

Figure 5: Begg's funnel plot of the potential publication bias of included studies. 
glands. The combined analysis showed that the positive expression rate of p53 in cribriform/ tubular SACC was $39.4 \%$ (168/426 cases), and that in solid SACC was $71.7 \%(104 / 145)$. Statistically significant heterogeneity was observed between the studies $\left(\mathrm{I}^{2}=50 \%, P=0.01\right)$. The combined analysis showed that the patients of the cribriform/ tubular type had a low expression of $\mathrm{p} 53$, and those of the solid type had a high p53 expression $(\mathrm{OR}=$ 0.32, 95 \% CI: $0.20-0.50, P<0.00001)$ (Figure 4).

Sensitivity analysis did not show any significant difference when meta-analysis was repeated after each individual study was omitted or after excluding studies. Regarding the publication bias in the studies, no funnel plot asymmetry was found. Furthermore, Begg's test was applied to provide statistical evidence for funnel plot symmetry. As expected, the P value of Begg's test was 0.303 (Figure 5). Hence, there was no evidence for significant publication bias in the meta-analysis.

\section{Meta-analysis of p53 expression in the different tumor} stages of $\mathrm{SACC}$

The association between p53 positive expression and tumor stage of SACC patients was investigated in 10 of 36 studies. The combined analysis showed that the positive expression rate of p53 among patients in T1and T2 stage was $41.4 \%(92 / 222$ cases $)$, and that among

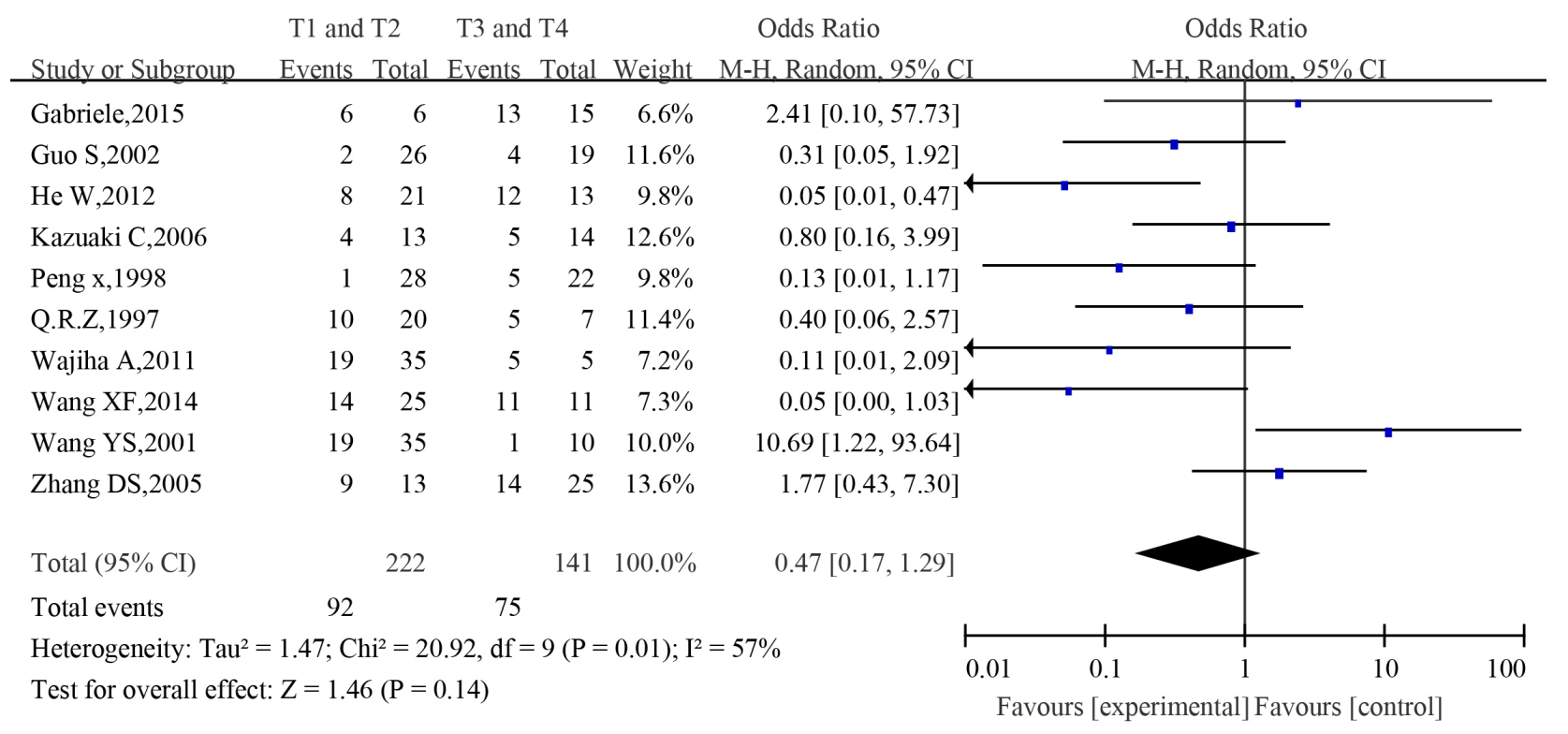

Figure 6: The forest plot of the meta-analysis between p53 expression in the T1/T2 and T3/T4 of salivary glands adenoid cystic carcinoma.

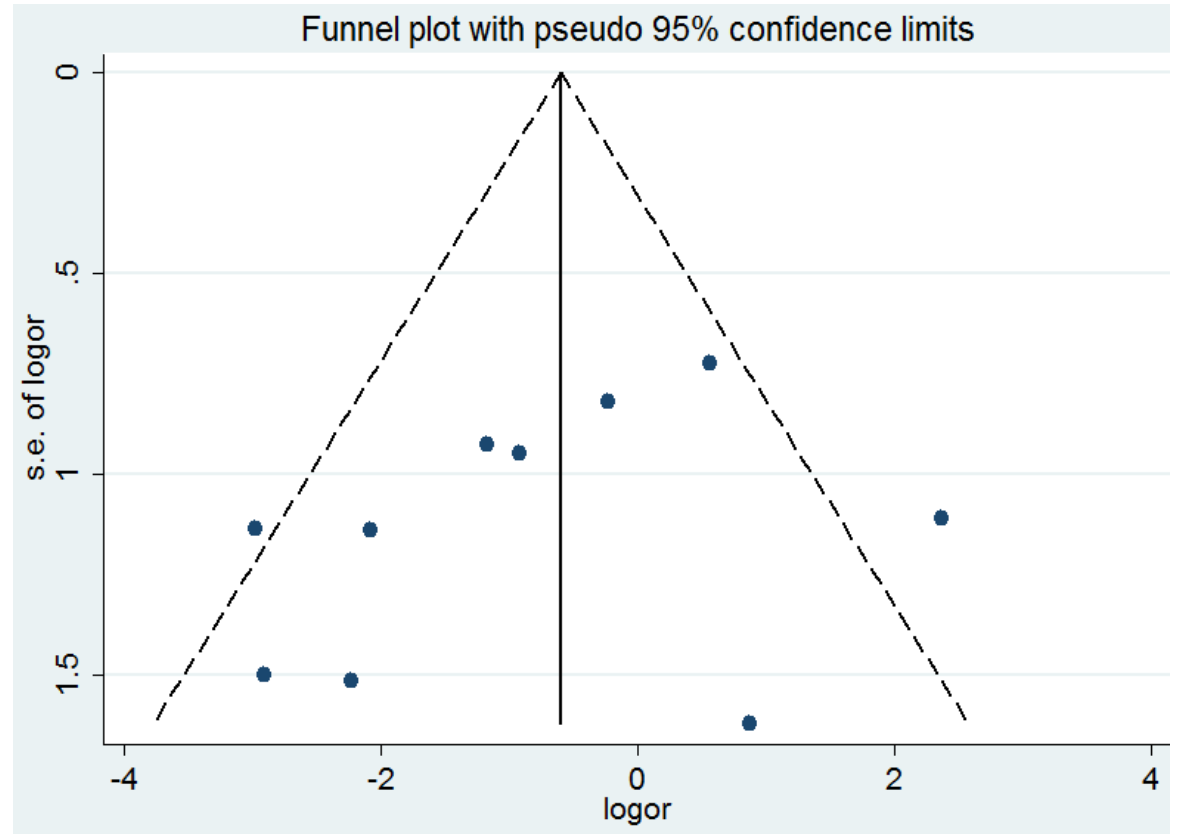

Figure 7: Begg's funnel plot of the potential publication bias of included studies. 
patients in T3 and T4 stage was 53.2\% (75/141 cases). The heterogeneity of the 10 studies was tested, and the statistically significant heterogeneity was observed between the studies $\left(\mathrm{I}^{2}=57 \%, P=0.01\right)$. The combined analysis showed that the positive expression rate of p53 in tumor in T3 and T4 stage was higher than that in T1 and T2 stage, however, no statistically significant correlation was observed between tumor stage and p53 expression $(\mathrm{OR}=0.47,95 \% \mathrm{CI}: 0.17-1.29, \mathrm{P}=0.14)$ (Figure 6).

No significant difference was observed among the studies in sensitivity analysis. At the same time, no funnel plot asymmetry was found in the studies and the Begg's test did not show any evidence of publication bias $(P=$ 0.371 ; Figure 7)

\section{Meta-analysis between $\mathbf{p 5 3}$ expression and metastasis of SACC}

The information concerning the association between p53 expression and metastasis of adenoid cystic carcinoma was provided in eleven studies. The combined analysis showed that the metastatic rate of patients with positive expression of p53 was $35.6 \%$ (77/216), and that of patients with negative expression of p53 was $22.2 \%$ (48/216). No significant heterogeneity was observed among the studies

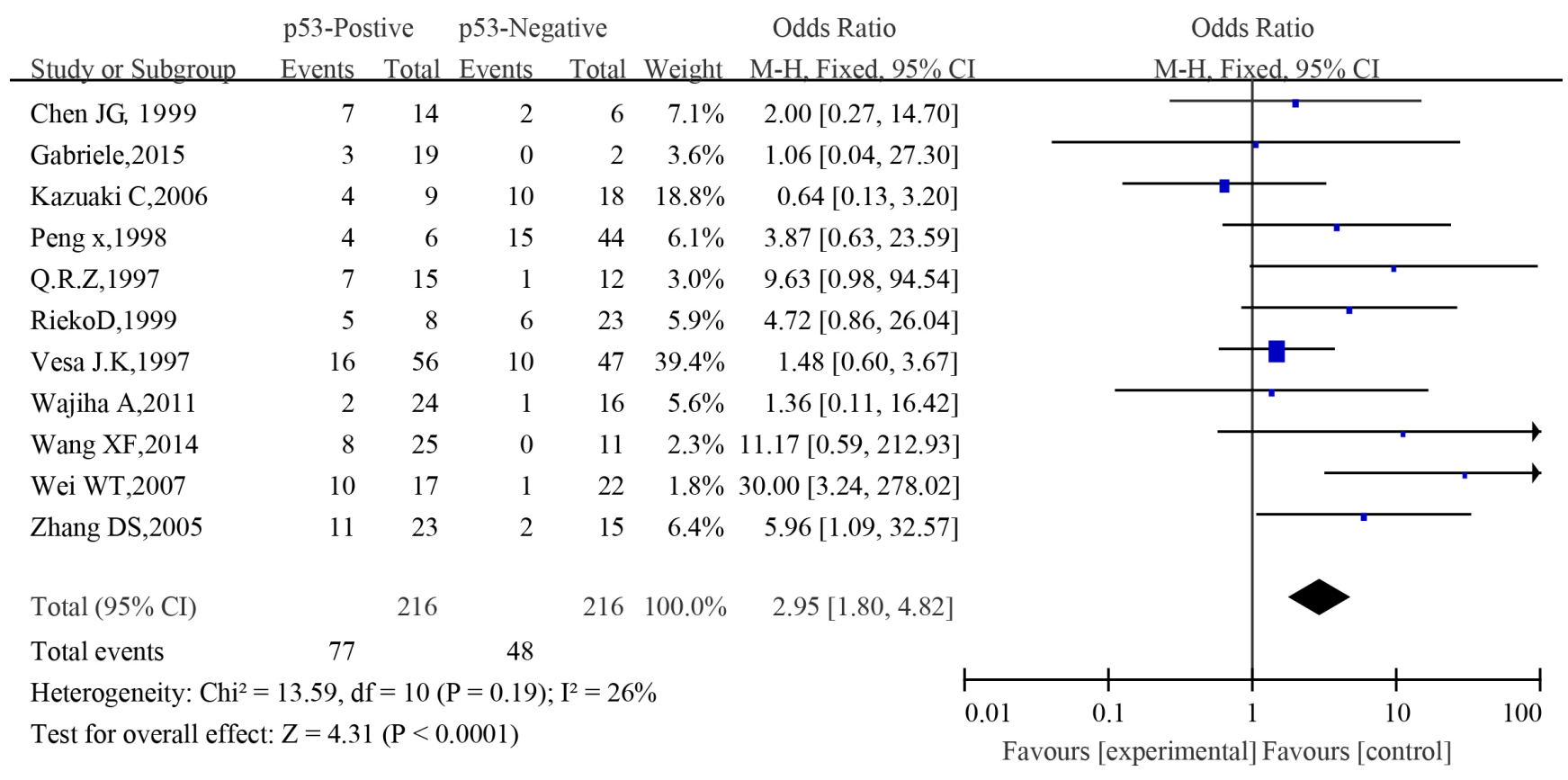

Figure 8: The forest plot of the meta-analysis between p53 expression and metastasis of salivary glands adenoid cystic carcinoma.

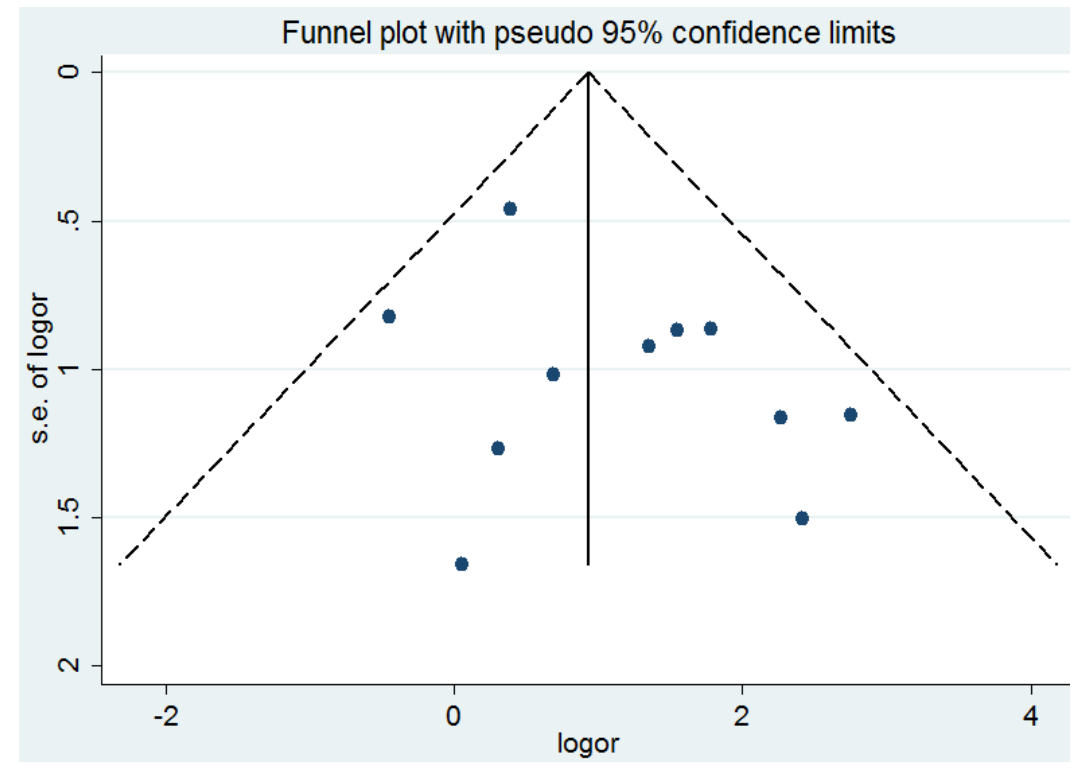

Figure 9: Begg's funnel plot of the potential publication bias of included studies 
on p53 expression and metastasis $\left(\mathrm{I}^{2}=26 \%, P=0.19\right)$. The combined analysis showed that compared to patients with negative expression of $\mathrm{p} 53$, those with positive expression of p53 had a greater chance of developing metastasis $(\mathrm{OR}=2.95,95 \% \mathrm{CI}, 1.80-4.82, P<0.0001)$ (Figure 8).

Similarly, no significant difference was observed among the studies in sensitivity analysis (Figure 12). At the same time, no funnel plot asymmetry was found in the studies and the Begg's test did not show any evidence of publication bias $(P=0.755$; Figure 9$)$.

\section{Meta-analysis between p53 expression and local recurrence of $\mathrm{SACC}$}

Eight eligible studies provided information concerning the association between p53 expression and local recurrence of SACC. The combined analysis showed that recurrence rate of patients with $\mathrm{p} 53$ positive expression was $43.1 \%(81 / 188)$, and patients with p53 negative expression was 20\%(29/145). A slight heterogeneity was observed in the pooled studies $\left(\mathrm{I}^{2}=38 \%\right.$, $P=0.12$ ). The combined analysis showed that compared

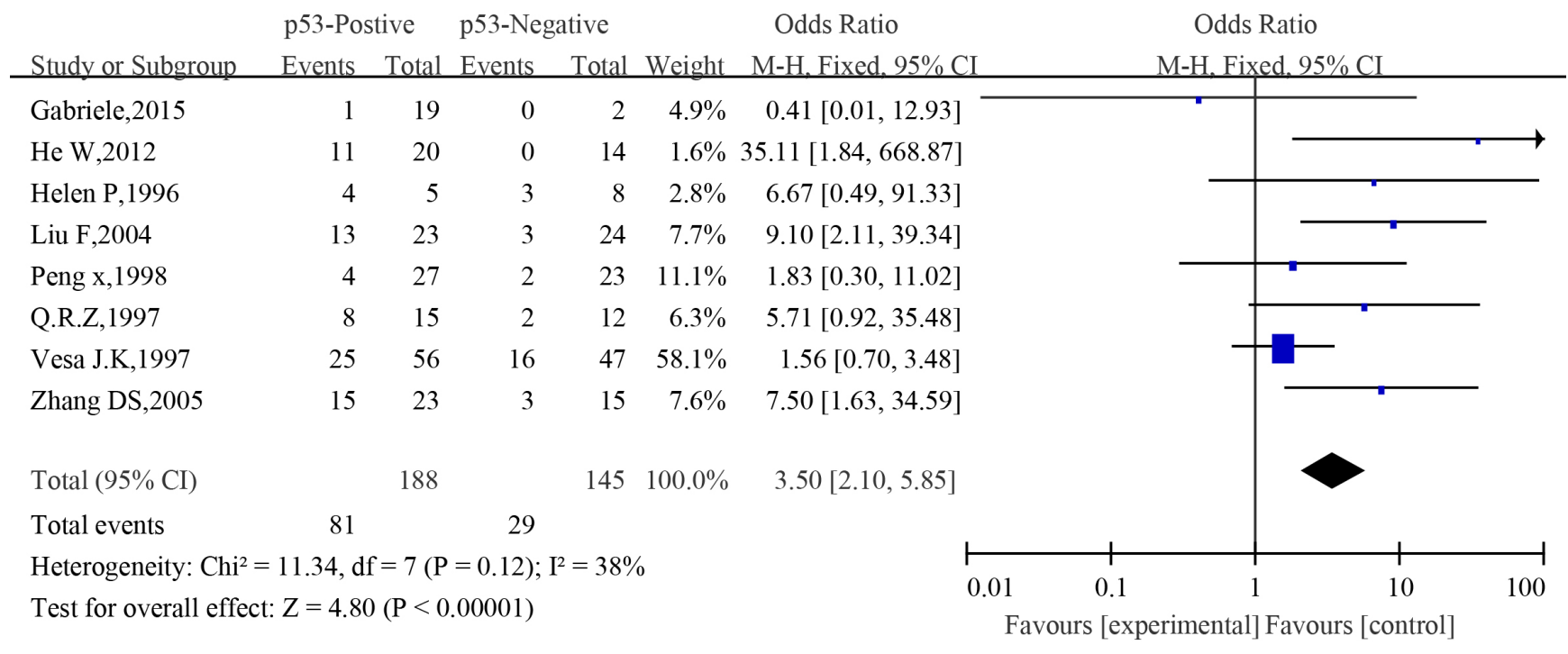

Figure 10: The forest plot of the meta-analysis between p53 expression and local recurrence of salivary glands adenoid cystic carcinoma.

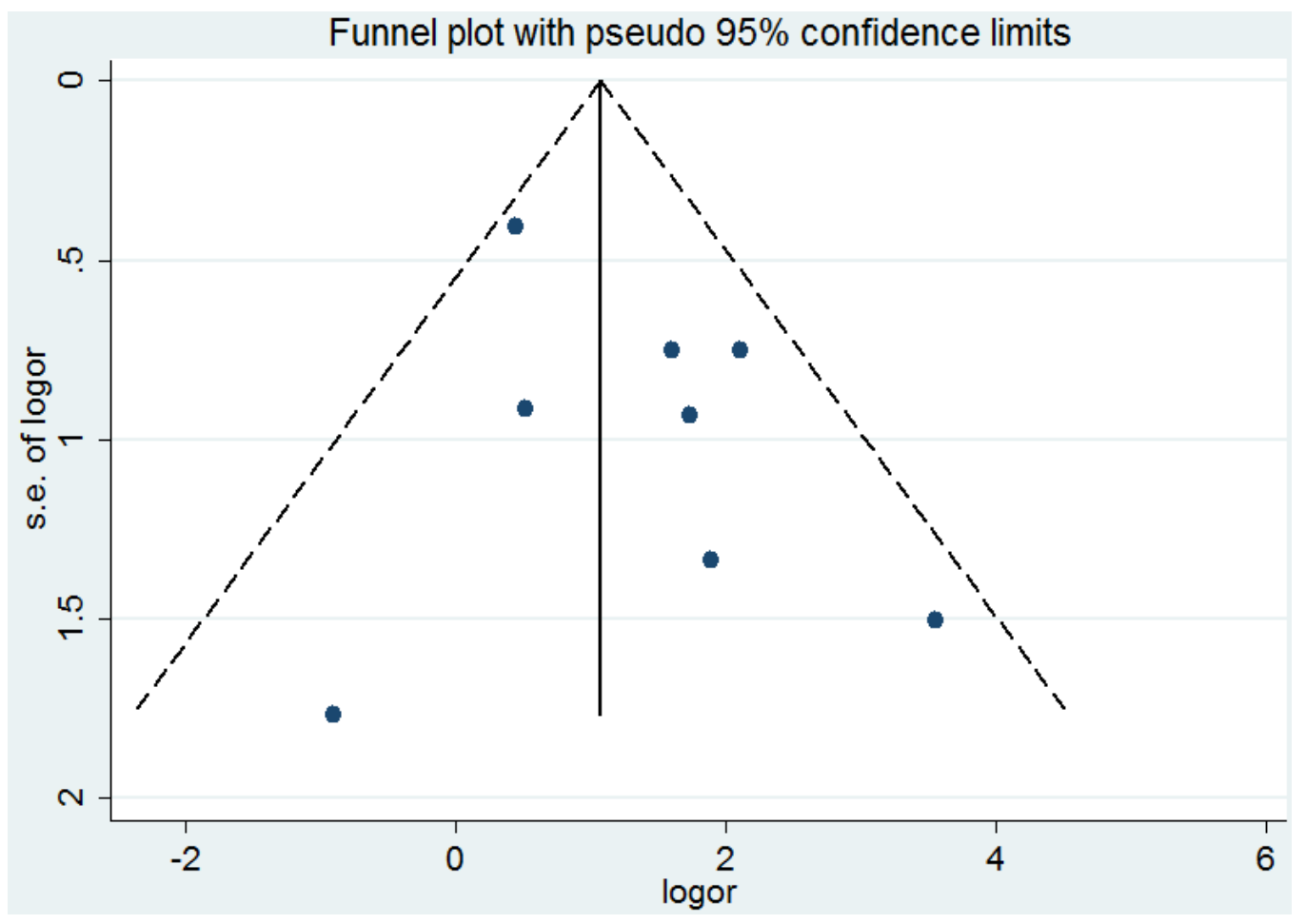

Figure 11: Begg's funnel plot of the potential publication bias of included studies. 
to patients with negative expression of $\mathrm{p} 53$, those with positive expression of p53 had a significantly higher incidence of local recurrence $(\mathrm{OR}=3.50 ; 95 \% \mathrm{CI}: 2.10$ 5.85, $P<0.00001$ ) (Figure 10).

Similarly, no significant difference was observed among the studies in sensitivity analysis. Similar results were found for investigating association between p53 positive expression and recurrence (a Begg's test score of $P=1.000$ ). Meanwhile, according to the funnel plot (Figure 11 , there was no publication bias in these analyses.

\section{Meta-analysis between p53 expression and 5-year survival of SACC}

The information concerning the association between p53 expression and 5-year survival of SACC was revealed by seven eligible studies. The combined analysis showed that the 5-year survival rate of patients with positive expression of p53 was $41.76 \%$ (37/89) compared to $70 \%$ (130/186) of patients with negative expression of p53. A slight heterogeneity was observed in the pooled studies $\left(\mathrm{I}^{2}=5 \%, \mathrm{P}=0.39\right)$. Meta-analysis results showed that compared to patients with negative expression of $\mathrm{p} 53$, those who had positive expression of p53 had significantly poorer OS $(\mathrm{OR}=0.28 ; 95 \% \mathrm{CI}, 0.16-0.50, \mathrm{P}<0.0001)$ (Figure 12).

Similarly, no significant difference was observed among the studies in sensitivity analysis . Begg's test was not significant, and the funnel plot for 5-year survival showed only slight asymmetry, which reduced the likelihood of significant publication bias(Figure 13).

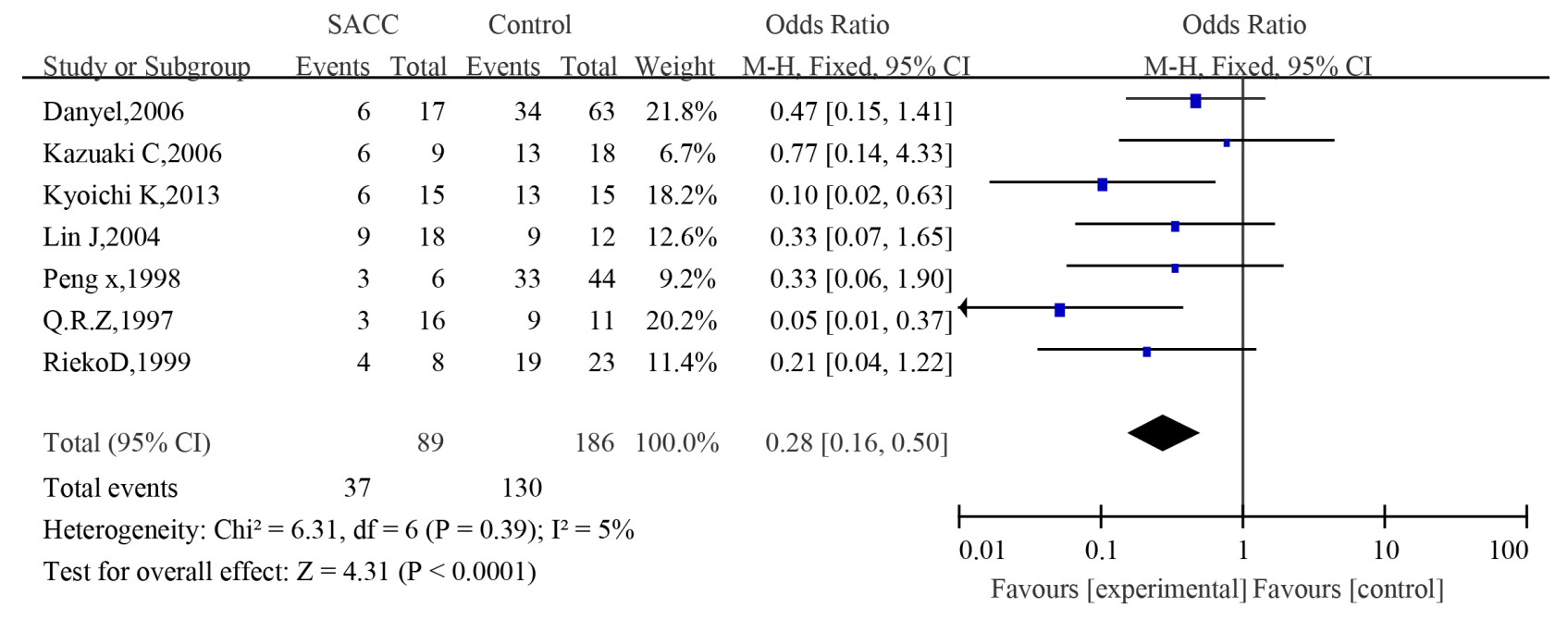

Figure 12: The forest plot of the meta-analysis between p53 expression and 5-year survival of salivary glands adenoid cystic carcinoma.

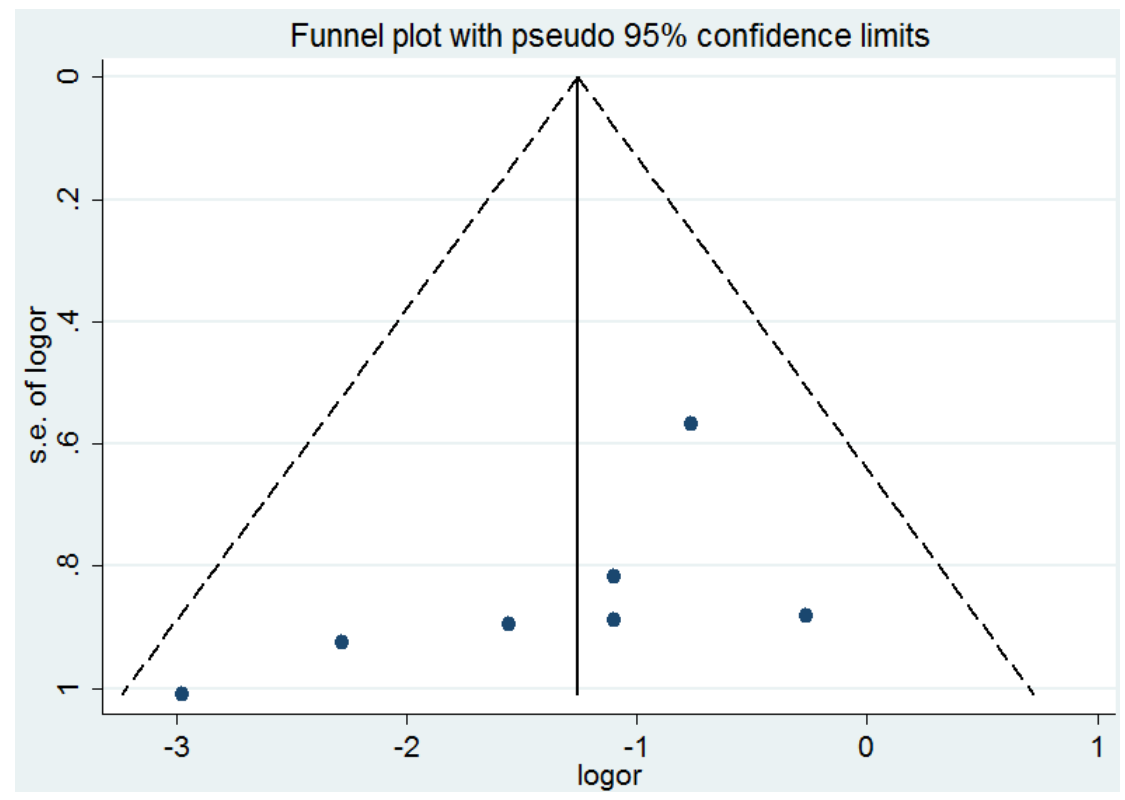

Figure 13: Begg's funnel plot of the potential publication bias of included studies. 


\section{Meta-analysis between p53 expression and nerve infiltration of SACC}

Three eligible studies provided information concerning the association between p53 expression and nerve infiltration of SACC. The combined analysis showed that the nerve infiltration rate of patients with positive expression of p53 was $46.7 \%(28 / 60)$, and that of patients with negative expression of p53 was $15 \%$ (6/40). No significant heterogeneity was observed among the studies on association between p53 expression and nerve infiltration $\left(\mathrm{I}^{2}=0, P=0.725\right)$. The combined analysis showed that compared to patients with negative expression of p53, those with positive expression of p53 had more chance of developing nerve infiltration $(\mathrm{OR}=3.03 ; 95 \% \mathrm{CI}$, 1.42-6.43, $P=0.002$ )(Figure 14).

Similarly, no significant difference was observed among the studies in sensitivity analysis . Similar results were found for investigating association between p53 positive expression and nerve infiltration (a Begg's test score of $P=1.000)$. Meanwhile according to the funnel plot(Figure 15), there were no publication bias in these analyses.

\section{DISCUSSION}

\section{Principal findings}

In this study, the relationship between p53 immunohistochemical expression and pathological types, clinical stage, local recurrence, metastasis(lymph node metastasis and distant metastasis), nerve infiltration and survival was statistically analyzed in order to investigate

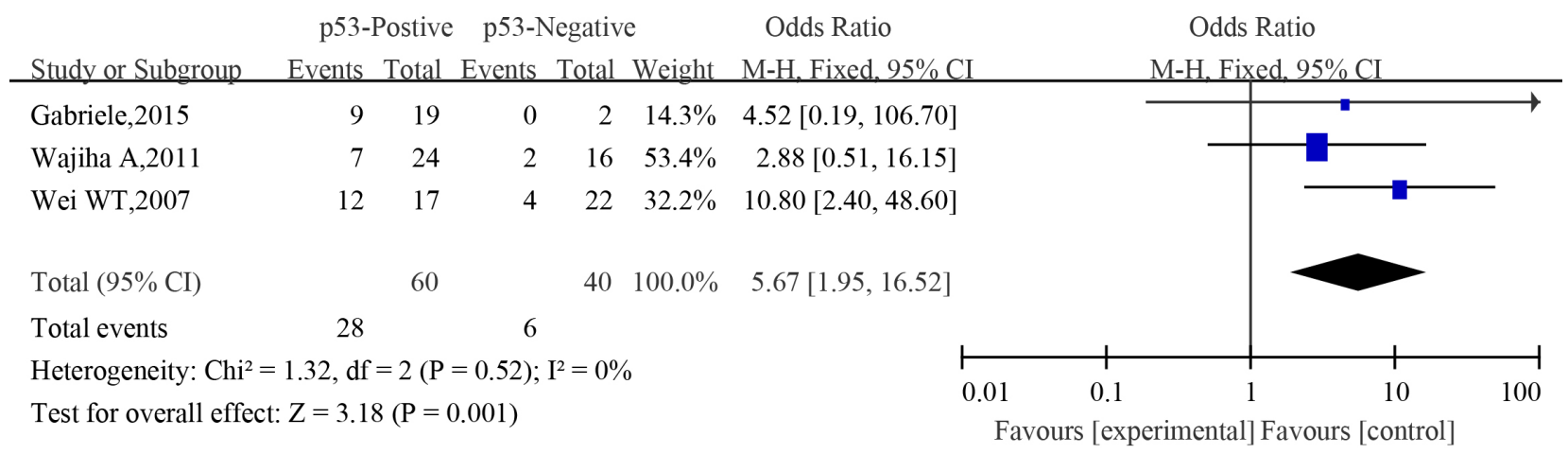

Figure 14: The forest plot of the meta-analysis between p53 expression and nerve infiltration of salivary glands adenoid cystic carcinoma.

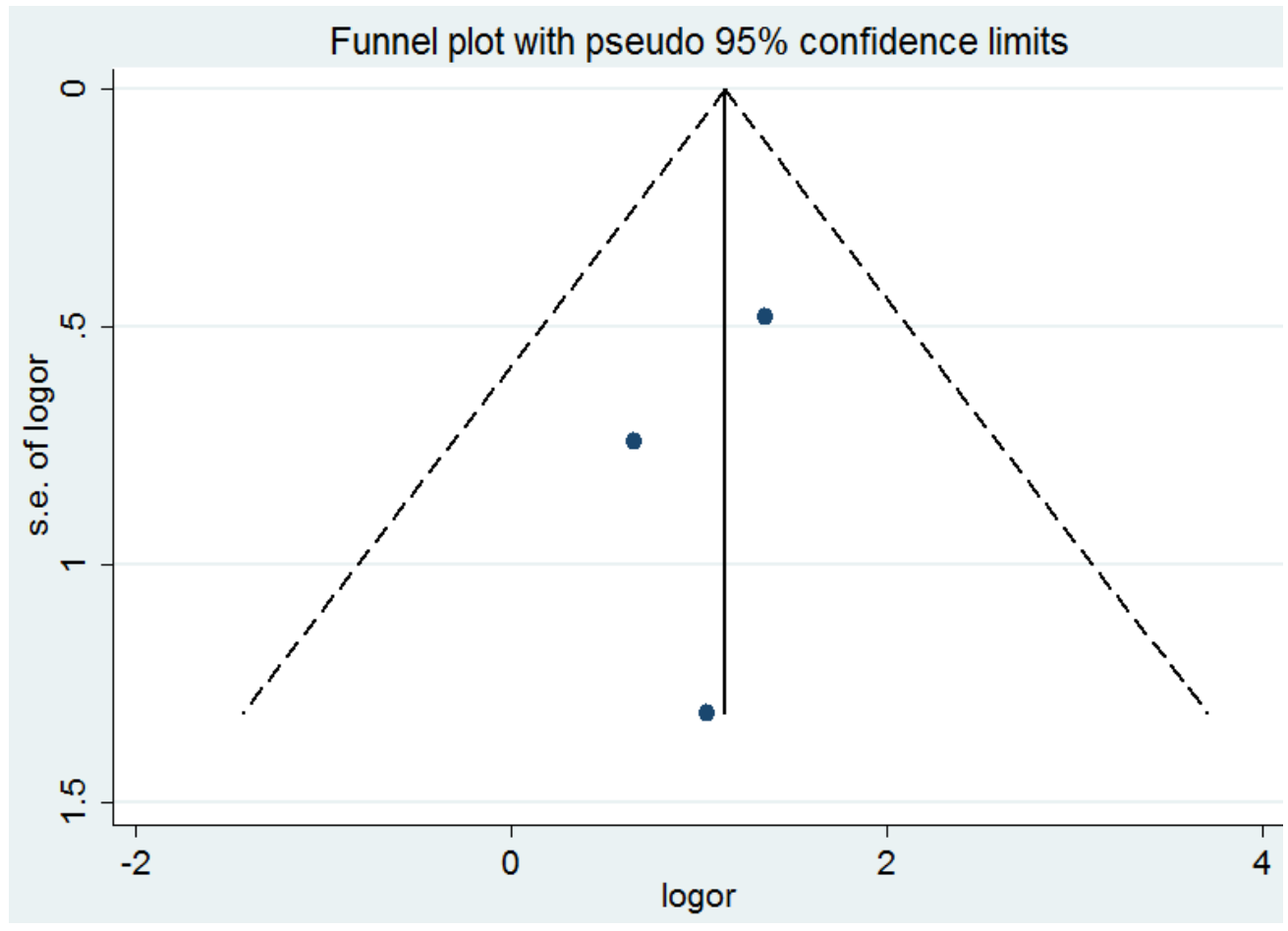

Figure 15: Begg's funnel plot of the potential publication bias of included studies. 
the association between positive expression of p53 and prognosis of SACC. The present meta-analysis has combined 36 publications including 1,608 patients to yield statistics, showing the following results: p53 was expressed at a high level in SACC tissues and the positive expression rate was $49 \%(\mathrm{OR}=10.34,95 \% \mathrm{CI}: 4.93-21.71$, $P<0.00001)$. The p53-positive expression was closely related to tumor types $(\mathrm{OR}=0.32,95 \% \mathrm{CI}: 0.20-0.50$, $\mathrm{P}<0.00001)$. Those with solid histological subtype tumor had a strong positive correlation with p53 expression. The combined analysis showed that positive expression rate of p53 among patients in T1 and T2 was $41.4 \%$, and that among patients in T3 and T4 stage was 53.2\%. However, no statistically significant correlation was established between tumor stage and p53 expression $(\mathrm{OR}=0.47$, 95\%CI: $0.17-1.29, P=0.14)$. Besides, when compared to patients with negative expression of p53, those with positive expression of p53 had more chance of developing metastasis, local recurrence and nerve infiltration as well as poorer 5-year OS $(P<0.01)$.

\section{Overview of the evidence}

In the present meta-analysis, most of the ORs from the included studies were from multivariate analyses adjusting for confounding factors. Indeed, the adjusted ORs are more accurate than the unadjusted ORs since they reduce the risk of bias from other possible confounding factors. Hence, the findings from the present meta-analysis provided strong evidence that could establish a correlation betweeen $\mathrm{p} 53$ protein expression and clinicopathological parameters in prognostic assessment of SACC at microscopic level. Finally, of note, our included study population was mainly from four continents including thirteen countries. Therefore, the present study extensively revealed the value of p53 protein expression in the prognosis of patients with SACC.

\section{Outcome and Prognosis}

In our study, the $\mathrm{p} 53$ positive expression rate of SACC was higher than that in control tissues $(\mathrm{P}=0.001)$, which indicated that p53 plays an important role in the development of SACC. In the solid type, the positive expression rate of p53 was higher than that of the cribriform and tubular type $(P<0.01)$. However, there was no significant difference between the cribriform and tubular type $(P>0.05)$. The prognostic effects of solid histopathology are controversial. Some believes it means a lower rate of survival when compared with the tubular or cribriform type, whereas others have shown that there is no relationship [46,47]. The combined analysis showed that the recurrence rate of patients with positive expression of p53 was $43.1 \%$, and that of patients with negative expression of p53 was $20 \%$. Compared to patients with negative expression of $\mathrm{p} 53$, those with positive expression had more chance of developing local recurrence $(P<0.01)$, indicating that the expression of p53 was closely related to the recurrence, which may be an important marker to reflect the biological characteristics of ACC and to judge the prognosis. Similarly, Helen et al demonstrated that the expression of p53 was closely related to the degree of differentiation and recurrence of ACC[24]. Through this study, it was concluded that the expression of p53 in SACC was related to the degree of differentiation and malignancy, p53 positive rates, poor differentiation, high degree of malignancy and poor prognosis.

Many studies reported presence of metastasis in SACC but no study has been conducted to demonstrate any correlation between metastasis (lymph node metastasis and distant metastasis) and p53 expression so far. In our study, it was found that compared to patients with negative expression of $\mathrm{p} 53$, those with positive expression of $\mathrm{p} 53$ had more chance of developing metastasis, and 35.6\% of the cases with positive expression of p53 exhibited metastasis. There was significant correlation between $\mathrm{p} 53$ expression and metastasis $(\mathrm{p}=0.001)$. It was suggested that overexpression of $\mathrm{p} 53$ protein was a high risk marker for the distant metastasis of salivary glands.

The combined analysis revealed that the positive expression rate of p53 among patients in T1and T2 stage was $41.4 \%$, and that among patients in $\mathrm{T} 3$ and $\mathrm{T} 4$ stage was $53.2 \%$. However, overall no statistically significant correlation was established between tumor stage and p53 expression $(p=0.14)$. Similarly, Coggi $G$ et al. demonstrated that the overexpression rate of p53 in $\mathrm{T} 4$ and $\mathrm{T} 3$ tumor was higher than that in $\mathrm{T} 1$ and $\mathrm{T} 2$ tumor. Therefore, they believed that the overexpression of p53 was the characteristic of advanced cancer [48]. Conversely, Gallo $\mathrm{O}$ et al. concluded that p53 overexpression and clinical stage of SACC were not related to each other [49]. Therefore, we think that the abnormal expression of p53 protein may not be an indicator of clinical stage.

The present meta-analysis combined seven publications including 275 patients to yield statistics, and indicated a significant role of p53 detected by IHC in predicting 5-year overall survival of SACC. The study showed that the 5-year survival rate of patients with positive expression of p53 was lower than that of patients with negative expression of $\mathrm{p} 53(P<0.001)$, which may be related to the sensitivity of tumor cells to radiotherapy and chemotherapy besides the predisposing invasiveness, local recurrence and metastasis of tumor cells with overexpression of $\mathrm{p} 53$.

\section{The potential tumorigenesis mechanism and prognostic value of $\mathbf{p 5 3}$-postive expression}

Tumor suppressor gene $p 53$ is one of the most tumor relevant genes to date, which is the most frequently 
mutated gene in human tumor [50]. In normal cells, p53 gene plays important physiological roles through encoding wild-type p53 protein. Wild-type p53 protein combines with multiple cancer proteins, inhibiting their effects on cell transformation. As a transcription factor, wild-type p53 protein can regulate expression of multiple genes, such as enhancing $p 21$ gene expression and inhibiting bcl-2 gene expression, and then inhibit cellular division and proliferation. Wild-type p53 protein can induce cell apoptosis through enhancing Bax gene expression and inhibiting $b c l-2$ gene expression, which can promote DNA damage repair through activating Gadd to sustain genome DNA integrity. Mutant p53 protein not only loses the primitive function of tumor suppression, but also may gain the function of oncogenes, such as causing over-proliferation and division of cells, leading to cellular malignant transformation, tumor development, increased tumor invasion, as well as radiotherapy and chemotherapy resistance[51]. The half-life of wild-type p53 protein is only $6 \mathrm{~min}-12 \mathrm{~min}$, and its content is very low in nuclei, which can be hardly detected by regular immunohistochemistry (IHC) method. However, the halflife of mutant-type p53 protein is as long as $4 \mathrm{~h}-12 \mathrm{~h}$, and it is accumulated in nuclei with high content. In other words, p53 protein is overexpressed, which is also the main product detected by IHC.

In our study, the positive rate of p53 protein overexpression was relatively high among various pathological types of SACC. It has been found that the overexpression of p53 gene is involved in selective tolerance of tumor cells to chemotherapeutic drugs. The multidrug resistance associated gene of tumor cells is mainly mdrl, and the wild-type p53 protein can inhibit the promoter activity of mdrl gene, and the mutant p53 gene protein can enhance the promoter activity. In order to obtain a good therapeutic effect, mdrl unrelated drugs, such as paclitaxel, may be used for the malignant tumor with overexpression of p53[52]. In addition, overexpression of p53 can induce tumor cells to have radiation tolerance, thus the tumor is not sensitive to radiotherapy [53].

\section{Limitations}

Study selection and data extraction were performed independently and reproducibly by two reviewers. We also explored heterogeneity and potential publication bias in accordance with published guidelines. The present meta-analysis may have several limitations that need to be addressed: Firstly, in spite of the comprehensive search strategy, we can not avoid the possibility of having missed relevant studies, in particular studies published in languages other than English and Chinese. Positive results tend to be accepted by journals, while negative results are often rejected or not even submitted. There may have been negative studies that were never published, and the original data of several studies could not be obtained.
Secondly, although this study has tried to collect all the relevant data, the potential publication bias is inevitable, and some data may be missed. The missed information may reduce the reliability of p53 expression as a prognostic indicator of SACC. Thirdly, the p53 positive standards of the included studies were not uniform, and some studies did not even give the specific criteria, which may also cause the heterogeneity of the studies. Fourthly, our analyses were based on retrospective studies rather than prospective studies, thus it was hard to effectively avoid recall and selection bias. Finally, our meta-analysis relied on publication other than individual patient data. Studies may have differed in the baseline characteristics of patients included (surroundings, race, age, sex and treatment). Thus a random effects model analysis was employed to compensate for these deficiencies.

In conclusion, our meta-analysis is the first study to systematically estimate the association between p53 positivity and survival of SACC. As determined in our meta-analysis, it was concluded that p53 expression was associated with histological subtypes, tumor stage, metastasis, local recurrence, nerve infiltration and 5 -year OS in SACC. Tumor of the solid subtype had a strong positive correlation with p53 expression. Besides, compared to patients with p53-negative expression, those with p53-positive expression had more chance of developing metastasis, local recurrence, nerve infiltration and poorer 5-year OS. To strengthen our findings, welldesigned prospective studies with better standardized assessment of prognostic markers are required to explore the relationship between p53 expression and survival of SACC. Hence, the above mentioned parameters can be considered important while planning the management which may need an aggressive approach in these cases. More researches are required for additional comprehensive prognostic assessment of SACC.

\section{MATERIALS AND METHODS}

\section{Search strategy and study selection}

The electronic databases PubMed, Embase, Cochrane Library, Web of Science and China National Knowledge Infrastructure were searched for studies to be included in the present meta-analysis. An upper date limit of June 2016 was applied, and no lower date limit was set. The terms of "ACC or Adenoid Cystic Carcinoma", "salivary glands or sialaden", "cancer or carcinoma or tumor or neoplasm", "p53" were used for searching. Relevant articles, abstracts, and review articles were selected and reviewed, and the reference lists from these sources were searched for additional trials. We also reviewed the Cochrane Library for relevant articles. The references listed in the identified studies were also used to 
complete the search.

All candidate studies were reviewed by two independent reviewers (Li QL and Wang JF). Discrepancies were resolved by discussion. Our search was initially narrowed based on the title followed by the abstract, and finally full papers were reviewed if they were categorized as relevant studies. All of the references from review papers and original reports were examined for further relevant studies. Studies eligible for inclusion in this meta-analysis met the following criteria:(1): The object of literature study should be human salivary gland tumor, and adenoid cystic carcinoma must be contained;(2) Immunohistochemistry (IHC) was used to measure p53 expression in the tumor tissue;(3) there was a standard to judge if p53 expression was positive or negative in the tumor tissue;(4) the full paper can be obtained;(5)when the same author reported the same patient population in more than one publication, only the most recent report or the most complete one was included in the analysis. Exclusion criteria: (1) the relationship between ACC and P53 expression was not investigated; (2) repetitively published literature; (3) the study in which the corresponding data cannot be extracted from the original literature; (4) animal experiment or a single case report.

\section{Data extraction and quality assessment}

The final articles included were assessed independently by two reviewers (Li QL and Wang JF). Disagreements were addressed by discussion with a third reviewer until the first two reviewers reached a consensus or by contacting experts if necessary. Data retrieved from the reports included the first author's name, publication year, patient source, control source, detection method, number of samples and histopathological patterns. If data from any of the above categories were not reported in the primary study, items were treated as "not applicable."We did not contact the author of the primary study to request the information.

Quality assessment of included primary studies was independently performed by two reviewers (Li QL and Wang JF) using the Newcastle-Ottawa Quality Assessment Scale (NOS) [54]. NOS scores of $\geq 6$ were defined as high-quality studies. Any disagreement was solved by discussion.

\section{Statistical analysis}

Review manager software (Version 5.2, The Cochrane Collaboration, Copenhagen, Denmark). and the Stata 12.0 statistical software (Stata Corporation, College Station, TX, USA) were used to perform the meta-analysis. Cochrane's Q statistic was used to evaluate the heterogeneity of the primary studies. The main results were displayed in the forest plots. If heterogeneity was not considered to be statistically significant $(\mathrm{p}>0.10$ or $\mathrm{I}^{2}<50 \%$ ), the data were analyzed using a fixed-effect model; otherwise, a random-effect model was chosen. Publication bias was first assessed by visual judgment of a funnel plot, and Begg's test was then performed for each pooled study groups. A series of sensitivity analyses were performed to determine the impact of pooled models or trials with incompatible factors on the overall results. The OR was calculated for all of the analyses. A statistical test with a p-value less than 0.05 was considered significant.

\section{ACKNOWLEDGMENTS}

The successful completion of this work need to thank the following researchers: Qinglin Li and Ping Huang formulated the concept for the review. Qinglin Li and Jiafeng Wang did the literature search, data extraction, data analysis, writing, and editing. Chuanming Zheng and Minghua Ge edited and reviewed the manuscript. Qinglin Li did the data analysis, writing, and editing.

\section{CONFLICTS OF INTEREST}

All authors declare that they have no conflict of interests.

\section{GRANT SUPPORT}

This work was also supported by Hi-tech Research and Development Program of China (863). Natural Science Program of Zhejiang Department of Finance (No. LY14H160014).

\section{REFERENCES}

1. Al-Abasi A, Hazim M, Sani A. Adenoid cystic carcinoma of the subglottic. Pak J Med Sci. 2007; 23:270-74.

2. Alamgir W, Sarfraz T, Qureshi SM, Khan SS, Janjua OS, Akhtar F. Expression of p53 in adenoid cystic carcinoma of salivary glands-a clinicopathological and immunohistochemical correlation. Pak J Pathol. 2011; 22:65-73.

3. Laurie SA, Ho AL, Fury MG, Sherman E, Pfister DG. Systemic therapy in the management of metastatic or locally recurrent adenoid cystic carcinoma of the salivary glands: a systematic review. Lancet Oncol. 2011; 12:815-24.

4. Kokemueller H, Eckardt A, Brachvogel P, Hausamen JE. Adenoid cystic carcinoma of the head and neck-a 20 years experience. Int J Oral Maxillofac Surg. 2004; 33:25-31.

5. Gondivkar SM, Gadbail AR, Chole R, Parikh RV. Adenoid cystic carcinoma: a rare clinical entity and literature review. Oral Oncol. 2011; 47:231-36.

6. Jung MJ, Roh JL, Choi SH, Nam SY, Kim SY, Lee SW, Cho KJ. Basal cell adenocarcinoma of the salivary gland: a morphological and immunohistochemical comparison with 
basal cell adenoma with and without capsular invasion. Diagn Pathol. 2013; 8:171.

7. Kaira K, Toyoda M, Shino M, Sakakura K, Takahashi K, Tominaga H, Oriuchi N, Kanai Y, Oyama T, Chikamatsu K. Clinicopathological significance of L-type amino acid transporter 1 (LAT1) expression in patients with adenoid cystic carcinoma. Pathol Oncol Res. 2013; 19:649-56.

8. Dodd RL, Slevin NJ. Salivary gland adenoid cystic carcinoma: a review of chemotherapy and molecular therapies. Oral Oncol. 2006; 42:759-69.

9. Spiro RH, Huvos AG. Stage means more than grade in adenoid cystic carcinoma. Am J Surg. 1992; 164:623-28.

10. Terhaard CH, Lubsen H, Van der Tweel I, Hilgers FJ, Eijkenboom WM, Marres HA, Tjho-Heslinga RE, de Jong JM, Roodenburg JL; Dutch Head and Neck Oncology Cooperative Group. Salivary gland carcinoma: independent prognostic factors for locoregional control, distant metastases, and overall survival: results of the Dutch head and neck oncology cooperative group. Head Neck. 2004; 26:681-92.

11. Lloyd S, Yu JB, Wilson LD, Decker RH. Determinants and patterns of survival in adenoid cystic carcinoma of the head and neck, including an analysis of adjuvant radiation therapy. Am J Clin Oncol. 2011; 34:76-81.

12. Ko YH, Lee MA, Hong YS, Lee KS, Jung CK, Kim YS, Sun DI, Kim BS, Kim MS, Kang JH. Prognostic factors affecting the clinical outcome of adenoid cystic carcinoma of the head and neck. Jpn J Clin Oncol. 2007; 37:805-11.

13. Jiang LC, Huang SY, Zhang DS, Zhang SH, Li WG, Zheng $\mathrm{PH}$, Chen ZW. Expression of beclin 1 in primary salivary adenoid cystic carcinoma and its relation to Bcl-2 and p53 and prognosis. Braz J Med Biol Res. 2014; 47:252-258.

14. Guo Shu, Wang Yuxin, Sun Changfu, et al. Expression and significance of protein kinase CK2-p and related P53 in salivary adenoid cystic carcinoma. Chinese Journal of histochemistry and cell chemistry. 2002; 04:454-457.

15. Peng Xin, Yu Guangyan, Gao Yan, et al. The expression of metallothionein, proliferating cell nuclear antigen and p53in salivary adenoid cystic carcinoma. Journal of modern oral medicine. 1998; 4:241-247

16. da Cruz Perez DE, de Abreu Alves F, Nobuko Nishimoto I, de Almeida OP, Kowalski LP. Prognostic factors in head and neck adenoid cystic carcinoma. Oral Oncol. 2006; 42:139-46.

17. Chikamatsu K, Shino M, Sakakura K, Nakajima K, Sakurai T, Miyashita M, Furuya N. Expression of thymidylate synthase and dihydropyrimidine dehydrogenase in adenoid cystic carcinoma of the head and neck: correlation with clinical outcome. Oral Oncol. 2007; 43:662-69.

18. Carlinfante G, Lazzaretti M, Ferrari S, Bianchi B, Crafa P. P53, bcl-2 and Ki-67 expression in adenoid cystic carcinoma of the palate. A clinico-pathologic study of 21 cases with long-term follow-up. Pathol Res Pract. 2005;
200:791-99.

19. Liu F, Zhang JZ, Ma M, Han ES, Li GF. Expression of p53, scoring of PCNA,Bcl-2 in human salivary adenoid cystic carcinoma and their correlation with the pathologic types and recurrence. J Clin Dent. 2004.

20. Jia L, Esguerra RL, Tang X, Yin H, Sakamoto K, Okada N, Takagi M. Prognostic value of apoptosis and apoptosisassociated proteins in salivary gland adenoid cystic carcinoma. Pathol Int. 2004; 54:217-23.

21. Barrera JE, Shroyer KR, Said S, Hoernig G, Melrose R, Freedman PD, Wright TA, Greer RO. Estrogen and progesterone receptor and p53 gene expression in adenoid cystic cancer. Head Neck Pathol. 2008; 2:13-18.

22. HE Wei, CHEN Yongji, LIU Caiyun, et al. Expression of p53, P-glycoprotein, GST and TopoII in salivary glands adenoid cystic carcinoma and its clinical significance. Modern cancer medicine 2012:1161-1164.

23. Kärjä VJ, Syrjänen KJ, Kurvinen AK, Syrjänen SM. Expression and mutations of p53 in salivary gland tumours. J Oral Pathol Med. 1997; 26:217-223.

24. Papadaki H, Finkelstein SD, Kounelis S, Bakker A, Swalsky PA, Kapadia SB. The role of p53 mutation and protein expression in primary and recurrent adenoid cystic carcinoma. Hum Pathol. 1996; 27:567-72.

25. Zhang DS, Wang WZ, Wu JL, et al. The relationship between the expression of p53 gene and clinicopathological features in salivary adenoid cystic carcinoma. Journal of Shandon Medicine. 2005; 45:3-4.

26. Doi R, Kuratate I, Okamoto E, Ryoke K, Ito H. Expression of p53 oncoprotein increases intratumoral microvessel formation in human salivary gland carcinomas. J Oral Pathol Med. 1999; 28:259-63.

27. Kiyoshima T, Shima K, Kobayashi I, Matsuo K, Okamura K, Komatsu S, Rasul AM, Sakai H. Expression of p53 tumor suppressor gene in adenoid cystic and mucoepidermoid carcinomas of the salivary glands. Oral Oncol. 2001; 37:315-22.

28. Ben-Izhak O, Laster Z, Araidy S, Nagler RM. TUNEL - an efficient prognosis predictor of salivary malignancies. Br J Cancer. 2007; 96:1101-06.

29. Wang XF, Li SC, Fang DJ, et al. Expression of Survivin and p53 in salivary adenoid cystic carcinoma. Oral medicine research. 2014; 30:635-637.

30. Wei WT, Liu QJ. Correlation among the expressions of E-cad, P53 and Bcl-2 proteins, lung metastasis and nerve infiltration of salivary adenoid cystic carcinoma. Journal of Lanzhou University (Medical Science Edition). 2007.

31. Al-Rawi NH, Omer H, Al Kawas S. Immunohistochemical analysis of $\mathrm{P}(53)$ and bcl-2 in benign and malignant salivary glands tumors. J Oral Pathol Med. 2010; 39:48-55.

32. Yamamoto Y, Wistuba II, Kishimoto Y, Virmani AK, Vuitch F, Albores-Saavedra J, Gazdar AF. DNA analysis at p53 locus in adenoid cystic carcinoma: comparison of 
molecular study and p53 immunostaining. Pathol Int. 1998; 48:273-80.

33. 32. Zhu YM, Zhang YC. Expression of proliferating cell nuclear antigen and $\mathrm{P} 53$ protein in adenoid cystic carcinoma of salivary gland. Medical Journal of Chinese People Health. 2003; 15:722-24.

34. de Lima MD, Marques YM, Alves SM Jr, Freitas VM, Soares FA, de Araújo VC, Pinto DS Jr, Mantesso A. MDM2, P53, P21WAF1 and pAKT protein levels in genesis and behaviour of adenoid cystic carcinoma. Cancer Epidemiol. 2009; 33:142-46.

35. Wang YS. P53, P170 type mutations in oral salivary gland adenoid cystic carcinoma of meaning. Shaanxi Medical Journal. 2011; 40:146-18.

36. $\mathrm{Hu} \mathrm{HQ}$, Liu W, Ma XJ, et al. Expression and significance of P53 protein, VEGF and CD34 in salivary adenoid cystic carcinoma. Military Medical Journal of Southeast China. 2013:592-593.

37. Alves FA, Pires FR, De Almeida OP, Lopes MA, Kowalski LP. PCNA, Ki-67 and p53 expressions in submandibular salivary gland tumours. Int J Oral Maxillofac Surg. 2004; 33:593-97.

38. Zhu QR, White FH, Tipoe GL. p53 oncoprotein accumulation in adenoid cystic carcinoma of parotid and palatine salivary glands. Pathology. 1997; 29:154-58.

39. Nordgard S, Franzen G, Boysen M, Halvorsen T. p53 protein expression in adenoid cystic carcinoma of the head and neck. Oncol Rep. 1997; 4:301-05.

40. Nordkvist A, Röijer E, Bang G, Gustafsson H, Behrendt M, Ryd W, Thoresen S, Donath K, Stenman G. Expression and mutation patterns of $\mathrm{p} 53$ in benign and malignant salivary gland tumors. Int J Oncol. 2000; 16:477-83.

41. Liu H. Study on the significance of macrophage migration inhibitory factor in the adenoid cystic carcinoma of salivary gland. Wuhan University. Doctoral Dissertation. 2013.

42. Wenghoefer M, Pantelis A, Dommisch H, Götz W, Reich R, Bergé S, Martini M, Allam JP, Jepsen S, MerkelbachBruse S, Fischer HP, Novak N, Winter J. Nuclear hBD-1 accumulation in malignant salivary gland tumours. BMC Cancer. 2008; 8:290.

43. Chen J, Tie Z, Li Q, et al. p53, bcl-2 and ki-67 expressions in adenoid cystic carcinoma and their clinic significances. $\mathrm{J}$ Clin Dent. 1999.
44. Gomes CC, Diniz MG, Orsine LA, Duarte AP, FonsecaSilva T, Conn BI, De Marco L, Pereira CM, Gomez RS. Assessment of TP53 Mutations in Benign and Malignant Salivary Gland Neoplasms. PLoS One. 2012; 7:1261.

45. Ming MA. Study on the relationship between increased activity and prognosis of adenoid cystic carcinoma of salivary gland. The Fourth Military Medical University. Master Thesis. 2002.

46. Husain Q, Kanumuri VV, Svider PF, Radvansky BM, Boghani Z, Liu JK, Eloy JA. Sinonasal adenoid cystic carcinoma: systematic review of survival and treatment strategies. Otolaryngol Head Neck Surg. 2013; 148:29-39.

47. Spiro RH, Huvos AG, Strong EW. Adenoid cystic carcinoma: factors influencing survival. Am J Surg. 1979; 138:579-83.

48. Coggi G, Bosari S, Roncalli M, Graziani D, Bossi P, Viale G, Buffa R, Ferrero S, Piazza M, Blandamura S, Segalin A, Bonavina L, Peracchia A. p53 protein accumulation and p53 gene mutation in esophageal carcinoma. A molecular and immunohistochemical study with clinicopathologic correlations. Cancer. 1997; 79:425-32.

49. Gallo O, Franchi A, Bianchi S, Boddi V, Giannelli E, Alajmo E. p53 oncoprotein expression in parotid gland carcinoma is associated with clinical outcome. Cancer. 1995; 75:2037-44.

50. Ecke TH, Schlechte HH, Schiemenz K, Sachs MD, Lenk SV, Rudolph BD, Loening SA. TP53 gene mutations in prostate cancer progression. Anticancer Res. 2010; 30:1579-86.

51. Wang L, Wang J, Li W, et al. The effect of p53 on expression of MDR1 in tumor and its research progress. Journal of Chinese medical engineering. 2010; 18:161-162.

52. Gan Y, Wientjes MG, Schuller DE, Au JL. Pharmacodynamics of taxol in human head and neck tumors. Cancer Res. 1996; 56:2086-93.

53. Yuan L. The relationship between the overexpression of p53 protein and the efficacy of radiotherapy in head and neck cancer. Journal of Chinese Radiation Oncology. 1997; 6:204-05.

54. Stang A. Critical evaluation of the Newcastle-Ottawa scale for the assessment of the quality of nonrandomized studies in meta-analyses. Eur J Epidemiol. 2010; 25:603-05. 